\title{
Tumpuan Harapan Petani di Utara Bumi Lamadukelleng 1992-2015
}

\author{
Rahmat Andika, Ahmadin, Patahuddin \\ Pendidikan Sejarah FIS UNM \\ andhikarahmat14@gmail.com
}

\begin{abstract}
Abstrak
Penelitian ini mengkaji tentang latar belakang pembangunan Bendung Awo dan bagaimana dampak keberadaan Bendung Awo bagi masyarakat yang telah memanfaatkan airnya untuk pertanian. Hasil penelitian ini menunjukkan bahwa latar belakang pembangunan Bendung Awo tidak terlepas dari program Repelita pada masa Orde Baru. Bendung Awo dibangun pada tahun 1992-1994 dan diresmikan oleh Bapak Presiden Republik Indonesia yakni Soeharto. Kemudian dalam perkembangannya setelah berfungsinya Awo I (1994), Awo II (1998) dan Awo III (2000) telah mengairi 5.250 ha lahan yang terdiri dari lahan potensial dan lahan produktif (sawah) hingga tahun 2015 areal pelayanan Irigasi Awo lebih dari 4000 ha lahan persawahan yang berada didua kecamatan yakni Keera dan Pitumpanua. Keberadaan Bendung Awo membawa dampak bagi masyarakat yang telah menggunakan air irigasi tersebut. Dampak palingan dirasakan masyarakat yakni meningkatnya aspek ekonomi karena pertanian dilaksanakan dua kali dalam setahun, yang tentunya meningkatkan produktivitas hasil pertanian. Penelitian ini menggunakan metode kualitatif. Terdiri dari heuristik, kritik, interpretasi, dan historiografi. Data diperoleh dengan melakukan wawancara dengan Kepala Kantor UPTD Bendung Awo, PNS Pengairan, pensiunan, petani dan mengumpulkan sumber arsip (dokumen-dokumen dari kantor UPTD) serta literatur-literatur yang berhubungan (buku, skripsi).
\end{abstract}

\section{Kata Kunci : Bendung Awo, Irigasi, Petani}

\begin{abstract}
Abstrack
This paper discusses the background of Awo Weir construction and how it impact the exictence of Awo Weir for people who have used their water for agriculture. The results of this study indicate that the background of Awo weir construction can not be separated from the Repelita program in the New Order era. Awo weir was built in 1992-1994 and inaugurated by the President of the Republic of Indonesia, Soeharto. Subsequently in its development after the functioning of Awo I (1994), Awo II (1998) and Awo III (2000) have irrigated 5,250 ha of land consisting of potential land and productive land (rice field) until 2015 Awo Irrigation service area of more than 4000 ha of land rice fields located in two districts namely Keera and Pitumpanua. The existence of Awo weir has a impact on the people who have used the irrigation water. The most perceived impact of society that is increasing the economic aspect because agriculture is implemented twice a year, which of certainly increases the productivity of agricultural products. This research method is using qualitative. Consisting fo heuristic, kritism, intrepretation and historiography. The data obtained by doing an interview with Head Office of the UPTD Awo Weir, civil servanst irrigation, rectires, farmers and archive (documents from the UPTD) and literature related (books, paper).
\end{abstract}

Keyword : Awo Weir, Irrigation, Farmer 


\section{A. Pendahuluan}

Tumpuan harapan petani di utara Bumi Lamadukkeleng yakni sebuah judul yang membahas salah satu bendung yang ada di wilayah utara Bumi Lamadukelleng (Wajo). Maksud dari tumpuan harapan petani adalah adanya bangunan air yakni Bendung Awo sebagai faktor mendasar yang menjadi tumpuan berlangsungnya pertanian terkhusus padi dimulai sejak berfungsi akhir 1994. Utara Bumi Lamadukelleng karena secara geografis Kecamatan Keera dan Pitumpanua berada di wilayah utara Kabupaten Wajo.

Pada permulaan tahun 1970-an pemerintah meluncurkan suatu program pembangunan pertanian yang dikenal secara luas dengan program Revolusi Hijau yang di masyarakat dikenal dengan program Bimas. Tujuan program tersebut untuk peningkatan produktivitas sektor pertanian, melalui penerapan paket teknologi modern ( Soetrisno, 1998).

Secara resmi diberlakukannya peraturan pemerintah yakni UndangUndang (UU) No. 11/1974 tentang Pengairan dan PP. No. 23/1982 tentang Irigasi. Pemerintah kemudian membangun berbagai sarana pertanian untuk meningkatkan hasil produksi pertanian diantaranya bendungan, bendung, irigasi, dan sebagainya. Bagi pertanian, untuk menentukan dalam usaha tani atau produksi tanaman, pengairan dan sistemnya mempunyai peranan yang sangat besar, dan hal ini akan menguntungkan atau tidak akan menguntungkan para petani pemakai air, akan sangat tergantung pada perencanaan rancangan jaringan pengairan yang dibuat untuk keperluan usaha tani tersebut.

Meski sebelumnya sudah ada dibangun sarana bangunan air seperti bendungan, bendung, waduk, dan juga irigasi. Namun undang-undang tersebut menandai beberapa pembangunan bendungan dan bendung terutama di Sulawesi Selatan sendiri. namun perlu ditekankan bahwa adanya perbedaan antara bendungan dengan bendung, sebagaimana penjelasan dibawah ini.

Bendungan adalah suatu bangunan air yang dibangun khusus untuk membendung (menahan) aliran air yang berfungsi untuk memindahkan aliran air atau menampung sementara dalam jumlah tertentu kapasitas atau volume air dengan menggunakan struktur timbunan tanah homogen (Earthfill Dam), timbunan batu dengan lapisan kedap air (Rockfill Dam), konstruksi beton (Concrete Dam) atau berbagai tipe konstruksi lainnya.

Bendung adalah suatu bangunan yang dibuat dari pasangan batu kali, bronjong atau beton, yang terletak melintang pada sebuah sungai yang tentu saja bangunan ini dapat digunakan pula selain irigasi, seperti keperluan air minum, pembangkit listrik atau untuk pengendalian banjir. Menurut macamnya bendung dibagi dua, yakni bendung tetap dan bendung sementara, bendung tetap adalah bangunan yang sebagian besar konstruksi terdiri dari pintu yang dapat digerakkan untuk mengatur ketinggian muka air sungai sedangkan bendung sementara adalah bangunan yang dipergunakan untuk menaikkan muka air di sungai, sampai pada ketinggian yang diperlukan agar air dapat dialirkan ke saluran irigasi dan petak tersier.

Konsep pengelolaan air dan sumbernya pada dasarnya mencakup upaya serta kegiatan pengembangan pemanfaatan dan pelestarian sumberdaya air berupa menyalurkan (redistribusing) air yang tersedia dalam konteks ruang dan waktu, dan komponen mutu dan komponen volume (jumlah) pada suatu wilayah untuk memenuhi kebutuhan pokok kehidupan makhluk hidup. Plate (1993) mengemukakan bahwa sistem pengelolaan air dan sumber air dalam rangka pemenuhan kehidupan masyarakat modern ini bersifat berkelanjutan, harus mampu mengantisipasi: (1) sistem itu sendiri karena usia, (2) kebutuhan masyarakat, (3) dalam kemampuan memasok ((supply) air (Robert, 2002). 
Hal yang paling utama ketika ingin meningkatkan hasil produksi adalah ketersediaan sumber air. Air merupakan sarana produksi yang paling pokok bagi petani dalam membangun usaha taninya. Maka dari itu karena demikian pentingnya air tersebut, pemerintah telah membuat program penyempurnaan, perbaikan dan pembangunan bendung sekaligus irigasinya. Bendung yang pada pokoknya merupakan kegiatan pengaturan air untuk memenuhi kepentingan pertanian dengan pemanfaatan air yang berasal dari air permukaan dan air tanah.

Salah satu bendung yang dibangun oleh pemerintahdi Sulawesi Selatan ialah Bendung Awo yang berada pada aliran Sungai Awo, terletak di Desa Awota, Kecamatan Keera, Kabupaten Wajo. Setelah disepakatinya kontrak kerjasama antara pemerintah dengan PT. Waskita Jaya Purnama pada tahun 1992. Akhirnya pada tahun tersebut pula Pembangunan Bendung Awo dimulai, dengan waktu pekerjaan bendung selama 2 tahun dan selesai pada tahun 1994. Bendung Awo ini diresmikan oleh Bapak Presiden Indonesia kedua yakni Bapak Soeharto pada tanggal 19 Desember 1995 (UPTD Bendung Awo , 1992).

Tujuan pembangunan proyek irigasi ini adalah untuk meningkatkan hasil produksi pertanian yang terdapat di Kecamatan Keera dan Pitumpanua, hal ini dapat dilihat diawal pembangunannya bendung ini mengairi 5.000 Ha lebih lahan pertanian yang terdiri dari lahan produktif dan lahan potensial utamanya sawah dengan kebutuhan air untuk mengairi areal 8,5 $\mathrm{m}^{3}$ /detik (UPTD Bendung Awo, 2010).

Hal ini sejalan dengan apa yang diungkapkan Seopardjo dalam bukunya bahwa tujuan pembangunan irigasi adalah (1) menjamin keberhasilan produksi tanaman dalam menghadapi kekeringan jangka pendek, (2) mendinginkan tanah dan atmosfir sehingga akrab untuk pertumbuhan tanaman, (3) mengurangi bahaya kekeringan, (4) mencuci atau melarutkan garam dalam tanah, (5) mengurangi bahaya pemipaan tanah, (6) melunakkan lapisan oleh dan gumpalangumpalan tanah, dan (7) menunda pertunasan dengan cara pendinginan lewat evaporasi (Pusposutrdjo, 2001). Dengan sasaran proyek adalah untuk meningkatkan produksi pertanian melalui pengembangan sumber daya air dan irigasi.

Dengan adanya pengaturan dan penyediaan air dalam jumlah yang cukup dan waktu yang tepat bagi setiap petani di Keera dan Pitumpanua, diharapkan terjadinya kenaikan produksi utamanya beras, sehingga dapat menunjang penyediaan pangan nasional. Oleh karena itu dapat dikatakan bahwa penerapan teknologi baru dalam bidang pertanian tidak akan berhasil guna apabila tidak dibarengi dengan pengaturan dan penyediaan air yang cukup. Untuk itu sasaran pemerintah dewasa ini untuk meningkatkan produksi pertanian yakni dengan perbaikan dan pembangunan proyek bendung, khususnya Bendung Awo dalam kaitannya dengan peningkatan taraf kehidupan dan kesejahteraan para petani.

Skripsi yang ditulis oleh Abd. Rahman yang berjudul Sejarah Irigasi Sanrego Kecamatan Kahu Kabupaten Bone (19801998) pada Jurusan Pendidikan Sejarah, Fakultas Ilmu Sosial, Universitas Negeri Makassar. Tulisannya ini membahas tentang bagaimana latar belakang proses pembangunan irigasi yang diawal pembanguannya mendapat dana dari Anggaran Pendapatan dan Belanja Negara (APBN), pada tahun 1985 proyek pembangunannya terhenti karena keterbatasan dana. Pada tahun 1978 pembangunan Irigasi Sanrego dilanjutkan dengan menggunakan dana dari Bank Dunia. Selain itu juga membahas tentang perkembangan dan pemanfaatan tentunya memberikan dampak kepada masyarakat yang berada di Desa Sanrego.

Perbedaan kajiannya terletak pada bagian tahap perencanaan, tulisan Abd. Rahman belum utuh membahas bagaimana tahap perencanaan secara mendetail sebelum pembangunan Irigasi Sanrego 
dimulai, sedangkan tulisan ini membahas secara detail urutan dimulai dari tahap perencanaan hingga tiba pada masa penandatanganan kontrak kerjasama pada tahun 1992. Selain itu pada saat pembangunan berlangsung Bendung Awo tidak tersendat karena persoalan dana. Pada poin dampak ekonomi sejarah irigasi sanrego hanya memaparkan dampak secara umumnya, pada tulisan ini menampilkan hasil produksi semenjak berfungsi irigasi yang berpengaruh ketika luas sawah irigasi bertambah.

Karya ilmiah yang lain dalam bentuk skripsi yang ditulis oleh Mujahida pada tahun 2005 dengan judul Bendung Benteng di Kabupaten Pinrang (1966-1998) pada Jurusan Pendidikan Sejarah, Fakultas Ilmu Sosial, Universitas Negeri Makassar. Skripsi ini membahas tentang latar belakang pembangunan bendung pada masa kolonial yang mengarahkan tenaga rakyat secara paksa dan tentunya menimbulkan kesengsaraan bagi masyarakat sekitarnya. Lebih lanjut membahas perkembangan dan pemanfaatan bendung diantaranya memberikan gambaran tentang bagianbagian bendung dan irigasi serta fungsinya masing-masing. Bagaimana dampak keberadaan Bendung Benteng bukan hanya untuk pengairan tetapi juga digunakan untuk keperluan air bersih dan sebagai pembangkit listrik dalam skala kecil.

Sama halnya dengan tulisan pertama, hasil karya skripsi Mujahida juga membahas latar belakang pembangunan namun tidak spesifik kepada proses pembangunan yang artinya semasa pembangunan Bendung Benteng di Pinrang didalam pembahasannya porsi penderitaan rakyat banyak ditampilkan. Perbedaan dari kajian Bendung Awo menampilkan proses pembangunan dalam beberapa tahap. Satu hal dari kajian Bendung Benteng yakni cakupannya lebih luas pada poin dampak karena bendung tersebut berfungsi sebagai irigasi, penyedia air baku, dan juga sebagai pembangkit listrik dalam skala kecil yang telah dinikmati masyarkat disekitar Bendung
Benteng sedangkan dampak keberadaan Bendung Awo hanya pada irigasi.

Batasan temporal yang dikaji pada tulisan ini yakni 1992-2015. Dimana tahun awal pembangunan Bendung Awo dimulai pada 1992 dan pada tahun 2015 terjadi pemeliharaan berkala yakni pengerukan karena pendangkalan di udik bendung yang dikerjakan mesin berat. Batasan spasial jurnal ini di wilayah Kecamatan Keera dan juga beberapa kajiannya di Kecamatan Pitumpanua. Batasan tematik kajian tulisan ini yakni Sejarah Sosial Ekonomi karena adanya dampak yang dirasakan masyarakat semenjak berfungsinya Bendung Awo.

\section{B. Metode Penelitian}

Sejak penelitian dan penulisan sejarah dilakukan secara ilmiah, maka penelitian dan penulisan sejarah menggunakan metode sejarah. Metode itu sendiri berarti suatu cara, prosedur, atau teknik untuk mencapai sesuatu tujuan secara efektif dan efisien (Daliman, 2015). Metode penelitian sejarah tersebut yakni heruistik, kritik, intrepretasi dan historiografi.

Heuristik artinya mencari dan mengumpulkan sumber-sumber sejarah yang terkait dengan topik penelitian. Pengumpulan data primer melalui wawancara (Bapak Andi Irwan ST, Abu Nawas, Akisman, Saharuddin, Ambo Asse, Supratman, Laodding, Loddang, dan Abd. Hamid) serta dokumen-dokumen yang tersimpan di kantor UPTD Bendung Awo (Dokumen Kontrak Kerjasama, Dokumen Tender Evaluasi, Peta Tata Letak Daerah Irigasi Awo) dan data-data dari Badan Pusat Statistik Kabupaten Wajo (1996, 1998, 2002, 2007, 2011, 2014, 2016). Sedangkan data sekunder diperoleh dari kajian literatur berupa buku yang ditulis oleh Pusposutardjo (2001), Loekman Soetrisno (1998), Robert J Kodoatie (2002), maupun skripsi yang dirulis oleh Abd. Rahman (2001) dan Mujahida (2005) yang yang tersedia di perpustakaan. studi sejarah yang akademis atau kritis memerlukan fakta-fakta yang telah teruji. 
Oleh karena itu, data-data yang diperoleh melalui tahapan heuristik terlebih harus dikritik atau disaring sehingga diperoleh fakta-fakta yang seobjektif mungkin. Kritik tersebut berupa kritik tentang otentitasnya (kritik ekstern) maupun kredibilitas isinya (kritik intern), dilakukan ketika dan sesudah pengumpulan data berlangsung. Sumber sejarah yang telah dikritik menjadi data sejarah ( Sjamsuddin, 2007 ). Data yang telah dikritik kemudian diinterpretasikan sehingga melahirkan fakta-fakta sejarah dapat diuraikan dan disatukan sehingga mempunyai makna yang berkaitan satu dengan yang lainnya. Setelah data dikumpulkan kemudian dikritik (seleksi) menjadi data sejarah dan kemudian dimaknai menjadi fakta, langkah terakhir adalah menyusun semuanya menjadi satu tulisan utuh berbentuk narasi kronologis atau disebut historiografi.

\section{Tinjauan Penelitian}

Penelitian tentang Bendung Awo berada di Daerah Aliran Sungai Awo Desa Awota Kecamatan Keera Kabupaten Wajo tepatnya berada di titik kordinat, Garis Lintang: 3. 7,5146 S dan Garis Bujur: 120. 36472 T. Pada saat pembangunan Bendung Awo berlangsung Desa Awota masuk dalam wilayah administratif Kecamatan Pitumpanua, hingga tahun 1995 Keera kemudian menjadi Kecamatan Perwakilan Keera dan secara resmi didefinitifkan pada tahun 1999 dengan nama Kecamatan Keera. (UPTD Bendung Awo, 2010)

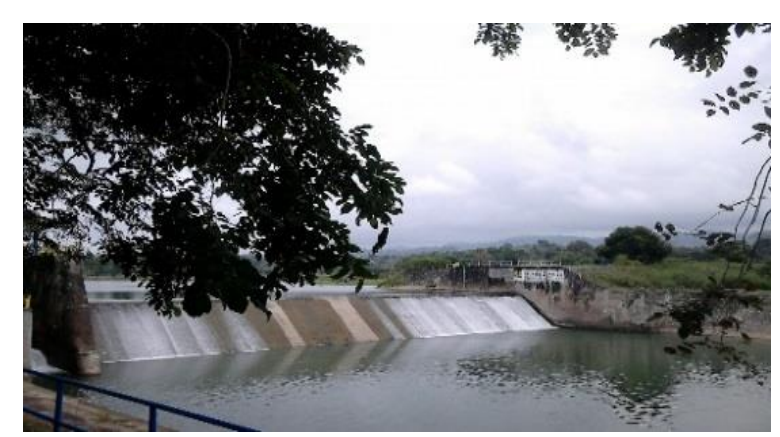

Sumber: Dukumentasi pribadi, 6 Oktober

2017

Foto ini menunjukkan bangunan mercu bedung yang melintang di aliran
Sungai Awo. Bagian barat pada gambar ini mengarah ke hulu sungai hingga ke pegunungan di Kabupaten Sidrap, bagian selatan ini bendung ini mempunyai dua pintu pengambil (intake) mendistribusikan air sungai ke saluran primer dan juga pondasi sebelah kiri, bagian timur bendung ini merupakan aliran sungai menuju Teluk Bone, dan bagain utara merupakan pondasi sebelah kanan bendung ini.

Faktor pendukung dipilihanya lokasi dalam penelitian tidak lain karena keberadaan Bendung Awo telah membawa manfaat dalam pertanian bagi masyarakat. Secara geografis Kecamatan Keera dan Pitumpanua mempunyai tofografi yang hampir mirip mempunyai beberapa wilayah bukit, areal persawahan dan juga tambak, hanya saja untuk Kecamatan Keera hanya sedikit areal persawahan yang dijangkau areal Irigasi Awo yakni 666 ha sedangkan Kecamatan Pitumpanua 2.326 ha, (Badan Pusat Statistik, 2002) mempunyai selisih angka hampir 4 kali lebih besar.

Secara demografis penduduk di Kecamatan Keera 21.414 dengan penduduk laki-laki 9169 dan perempuan 9.087 jiwa. Gambaran tentang kegiatan perekonomian di Kecamatan Keera berkisar $70 \%$ bertumpu pada pertanian selebihnya $30 \%$ terdiri dari tambak, perkebunan, perdagangan, jasa, pegawai negeri (Badan Pusat Statistik, 2002).

\section{Pembahasan}

\section{Pembangunan Bendung Awo}

Peran sektor pertanian sangat strategis dalam perekonomian nasional dan kegiatan ini tidak terlepas dari sumber air. Oleh sebab itu, irigasi sebagai salah satu komponen pembangunan pertanian mempunyai peranan penting. Adanya perubahan tujuan pembangunan dari meningkatkan produksi swasembada beras menjadi melestarikan katahanan pangan, meningkatkan pendapatan petani, meningkatkan kesempatan kerja di pedesaan dan perbaikan gizi keluarga, serta sejalan dengan semangat demokrasi dan keterbukaan dalam kehidupan masyarakat 
JURNAL PATTINGALLOANG

CJurusan Pendidikan Sejarah Fakultas Ilmu Sosial Universitas Negeri Makassar

perlu menetapkan kebijakan pengembangan dan pengelolaan sistem irigasi.

Pada pertengahan 1980an pemerintah melalui Direktorat Jenderal Pengairan mengadakan proyek irigasi berskala kecil di Sulawesi Selatan. Proyek tersebut beri nama South Sulawesi Irrigation Project: Small Scale Irrigation Management Project (SSIMP). Proyek irigasi ini nantinya membawahi beberapa pembangunan irigasi di Sulawesi Selatan yang skalanya kecil. Proyek irigasi yang termasuk dalam SSIMP yakni Irigasi Awo, Irigasi Ongkoe, Irigasi Padang Sappa, Irigasi Pabbela, dan Irigasi Macero (Laodding, 2018).

Pembangunan Bendung Awo dimulai dari tahap perencanaan. Pada tahap perencanaan Bendung Awo ada serangkaian aktivitas yang dilakukan oleh para konsultan yang ditugasi oleh pemerintah untuk mempelajari segala aspek yang berkaitan dengan lokasi pembangunan. Serangkaian aktivitas yang dilakukan sebelum pembangunan diawali sekitar akhir tahun 1988 beberapa konsultan turun untuk melakukan survei atau studi kelayakan tanah, penyusunan desain, dan pengadaan tanah serta memperhatikan kondisi sumber daya air, keberadaan masyarakat, benda bersejarah, dan daya dukung lingkungan hidup (Permen PUPR RI No. 27 / PRT / M / 2015 tentang Bendungan). Kegiatan survei yang dilaksanakan oleh para konsultan ini sebelumnya telah memiliki acuan atau standar apa saja yang akan mereka lakukan di lokasi survei. Hal ini didukung oleh pernyataan Bapak Laodding yang mengatakan bahwa,

"Sebelum dibangun itu Bendung Awo sama irigasinya banyak sekali nakerja itu konsultan mulai dari survei tempat sekitar yang akan dibanguni, sudah itu nainvestigasi lagi nabuatkanmi desain karena ini na ikuti memang petunjuk dari pemerintah. Sekitar 2 sampai tiga tahun nakerja itu survei saja” (Laodding, 2018).
Keterangan Laodding ini semakin memperjalas bahwa hadirnya para konsultan bekerja berdasarkan acuan dari pemerintah berada di lokasi survei sekitar 2 sampai 3 tahun untuk memperhitungkan segala aspek yang berpengaruh nantinya jika pembangunan berlangsung.

Tercatat bahwa ada dua kali turun survei lapangan yang dilakukan langsung oleh konsultan dari pusat bersama dengan konsultan dari Amerika dalam hal ini PT.

Dacrea Design and Engineering Consultansts yang mengeluarkan Peta Desain Tata Letak Umum Daerah Irigasi Awo pada tahun 1989 (desain tersebut belum termasuk wilayah Awo III) yang disepakati oleh Bapak H. Syamsul Arida, Dpil. HE selaku Pimpinan Proyek Irigasi Sulawesi Selatan SSIMP. Konsultan yang turun pada tahap kedua berlangsung setelah terbit desain untuk mempermantap hasil konsultan tahap pertama (Akisman, 2017).

Data ini menunjukkan bahwa sebelum dibangunnya Bendung Awo sangat perlu dilakukan proses survei guna untuk memperhitungkan segala hal yang akan menjadi dampak dari pembangunan Bendung Awo tersebut seperti survei kelayakan tanah, dampak social. Dalam proses survei berlangsung memerlukan waktu yang lama dan dilaksanakan dengan sebenarnya-benarnya sesuai petunjuk peraturan terkait serta dilaksankan oleh para konsultan yang ahli dalam bidangnya. Sebagaimana data diatas dua kali turun survei untuk mengetahui lokasi seluruhnya disekitaran areal tempat bangunan nantinya. Bahkan setelah konsultan pertama menyelesaikan tugasnya pada tahun 1989 dengan mengeluarkan desain peta tata letak dan pada tahun 1990 masih turun konsultan kedua untuk mempermantap hasil dari konsultan pertama tersebut.

Pada tanggal 4 September 1991, PT. Waskita Jaya Purnama menjadi pemenang tender untuk proyek Irigasi Awo dengan nilai tender Rp. 6.886.303.622,00. Dana ini berasal dari Amerika yakni USAID sebagai 
pinjaman kepada Indonesia untuk membangun Bendung Awo dan Irigasi Awo I ( UPTD Bendung Awo, 1993). Pada tanggal 6 Januari 1992 disepakatilah kontrak kerjasama untuk pembangunan Irigasi Awo dengan nomor: KU. 08.08 / SSIMP / 006 / 91-92.

Pengerjaan Bendung Awo I pun dimulai, pertama pembelokan arah sungai yang menjadi objek pembangunan mercu. Hal ini tentu dilakukan agar pembangunan tidak terhambat karena air sungai. Data yang didapatkan dalam arsip pembangunan dalam bentuk foto bahwa masih ada pengerjaan yang memompa air di sekitar bangunan mercu karena resapan air sungai yang sudah dibelokkan. Jadi air sungai tetap menjadi hambatan pembangunan, namun tidak berarti dalam pengerjaan konstruksi betonnya.

Pada saat pembangunan berlangsung pihak kontruktor juga menggunakan tenaga tambahan yang digaji oleh mereka untuk menyelesaikan beberapa pekerjaan. Pengerjaan konstruksi bendung dikerjakan oleh alat-alat berat milik PT. Waskta Jaya Purnama karena memang pengerjaannya sulit dan tenaga manusia mengerjakan beberapa saja bisa diselesaikan manusia, sedangkan untuk tenaga manusia banyak dipakai untuk membangun saluran tersier dan kwarter, perhitungan waktu kerja dengan upah Rp. 500/hari. (Loddang, 2018).

Data ini menunjukkan pada masa pembangunan PT. Waskita Jaya Purnama tidak semata-mata hanya menggunakan tenaga ahli dari perusahaannya sendiri. Dengan demikian pihak konstrutor juga membutuhkan tenaga manusia (masyarakat) disekitar lokasi pembangunan. Hal ini dibutuhkan untuk membantu menyelesaikan pengerjaan saluran tersier dan kwarter dengan diupah 500/hari.

Pada tahun 1994 bangunan Bendung Awo dengan Saluran Induk Awota dan Pangi serta Saluran Sekunder Kaluku dan Simpellu telah selesai dibangun. Saluran ini kemudian difungsikan oleh Dinas Pengairan bersama dengan PT. Waskita
Jaya Purnama sebagai percobaan untuk mengetahui hasilnya. Keberhasilan dari berfungsinya saluran ini langsung dinikmati oleh masyarakat yang berada di sekitar aliran Irigasi Awo I terkhusus lahan pertanian yang berada di aliran Saluran Induk Awota dan Pangi dan Saluran Sekunder Kaluku air dari bendung sudah bisa dialiri untuk lahan pertanian, sedangkan Saluran Sekunder Simpellu belum bisa dilalui karena pembangunan jembatan sekaligus talang air belum selesai. Solusi untuk tetap melakukan percobaan pengairan di Saluran Sekunder Simpellu airnya di pompanisasi dari Sungai Awo sendiri. Setelah pembangunan Jaringan Irigasi Awo I rampung secara keselurahan bersamaan dengan irigasi lainnya yang terrgabung dalam Proyek Irigasi Sulawesi Selatan SSIMP diresmikan di Makassar pada tanggal 19 Desember 1995 oleh Bapak Presiden Republik Indonesia yakni Soeharto.

Pembangunan irigasi ditahap ini berlanjut setelah selasainya Irigasi Awo I yakni pada akhir tahun 1995 dan pembangunannya selesai pada tahun 1998. Berdasarkan data yang ditemukan pembangunan jaringan Irigasi Awo II tidak lagi menggunakan dana yang dari USAID melainkan pihak pemberi dana yang digunakan dari OECF dari negara Jepang. Pihak konsultan yang mengawal untuk pembangunan Awo II yakni Nippon Koei yang berasosiasi dengan PT. Indah Karya .Hal yang tidak berubah dalam proyek Irigasi Awo II yakni pihak konstruktor tetap PT. Waskita Jaya Purnama (UPTD Bendung Awo, 1997).

Data ini menunjukkan adanya perubahan pada pola pendanaan yang sebelumnya diberikan oleh USAID dari Amerika Serikat kemudian beralih ke OECF dari Jepang. Meskipun demikian tidak terjadi penghambatan kerja karena masalah pendanaan.

Proyek Irigasi Awo II membuat Saluran Sekunder Bulete, Saluran Sekunder Bocco-Bocco, Saluran Sekunder Bakke, Saluran Sekunder Bulu Awo 
Kanan, Saluran Sekunder Padangloang, saluran Sekunder Leworeng, dan Saluran Sekunder Masiae. Dalam pengerjaannya sama dengan di Awo I juga melibatkan masyarakat yang digaji terkhusus dalam membuat Saluran Tersier dan Kwarter. Pembangunan Awo II yang dimulai tahun 1995, diujicobakan pada tahun 1997 dan rampung pada tahun 1998.

Pada tahun 1999 pembangunan Awo III dimulai. Sama halnya dengan pembangunan Awo II pembangunan Awo III juga menggunakan dana dari OECF. Pihak-pihak yang masih terlibat dalam pembangunan Awo III masih sama yakni Hary A Claark bersama dengan PT. Waskita Jaya Purnama selaku pihak konstruktor dan Nippon Koei selaku pihak konsultan nantinya. Proses pembangunannya pun dimulai pada tahun 1999 dengan melanjutkan pembangunan Irigasi Sekunder dari Masiae menuju ke arah selatan untuk membangun Saluran Sekunder Laukku dan Saluran Sekunder Keera.

Pembangunan Awo III rampung pada tahun 2000. Dengan rampungnya pembangunan proyek Irigasi Awo III menandai telah rampung keseluruhan Proyek Irigasi Sulawesi Selatan SSIMP untuk Daerah Irigasi Awo yang meliputi sekitar 5.250 ha yang terdiri dari lahan potensial dan lahan produktif. Daerah Irigasi Awo ini mengairi lahan persawahan yang berada didua kecamatan yakni Kecamatan Keera sekitar $30 \%$ lahan persawahan dan Pitumpanua sekitar 70\% lahan persawahan (Irwan, 2018).

\section{Dampak Keberadaan Bendung}

a. Pertambahan Luas Lahan Persawahan

Keberadaan Bendung Awo tidak bisa dipungkiri telah membawa dampak pada perluasan lahan pertanian sebagaimana ketika dikeluarkannya Desain Tata Letak Daerah Irigasi Awo pada tahun 1997 memberikan gambaran bahwa luas lahan potensial yang di Kecamatan Pitumpanua pada saat itu (1999 terbagi menjadi Keera dan Pitumpanua) mencapai 5.250 ha yang terdiri dari sawah dan berpotensi jadi sawah.

Tabel 4.1 Luas Sawah Irigasi di Kecamatan Keera dan Pitumpanua

\begin{tabular}{|c|c|c|c|}
\hline \multirow{2}{*}{$\begin{array}{l}\text { Tahu } \\
\mathrm{n}\end{array}$} & \multicolumn{2}{|c|}{$\begin{array}{l}\text { Luas Lahan } \\
\text { Persawahan (Ha) }\end{array}$} & \multirow[t]{2}{*}{ Jumlah } \\
\hline & Keera & $\begin{array}{l}\text { Pitumpa } \\
\text { nua }\end{array}$ & \\
\hline 1998 & - & 2.600 & 2.600 \\
\hline 2002 & 666 & 2.326 & 2.992 \\
\hline 2006 & 666 & 2.344 & 3.010 \\
\hline 2010 & 669 & $2.325,50$ & $\begin{array}{l}2.994,5 \\
0\end{array}$ \\
\hline 2013 & 838 & 3.473 & 3.473 \\
\hline 2015 & 838 & 3.523 & 4.361 \\
\hline
\end{tabular}

Sumber:. (BPS, 1998, 2002, 2007, 2011, 2014, 2016)

Tabel diatas menunjukkan bahwa luas sawah irigasi di Kecamatan Keera dan Pitumpanua mengalami peningkatan besar berkisar 10 tahun setelah difungsikan. Luas areal persawahan irigasi sepanjang difungsikan Bendung Awo hingga tahun 2015 beberapa ada yang tidak terlalu signifikan dan beberapa tahun juga mengalami peningkatan pesat seperti pada tabel. Pada tahun 1998 total sawah irigasi 2.600 ha yang berada di Kecamatan Pitumpanua, mangingat pada tahun 1998 irigasi Awo III belum dibangun sehingga sawah irigasi tersebut masih merupakan akumulasi dari Awo I dan Awo II. Lahan persawahan irigasi seluruhnya masih tergabung di Kecamatan Pitumpanua pada 
tahun 1998. Sehingga pada tahun 2002 pencatatan tentang luas sawah irigasi di Kecamatan Keera sudah tidak bergabung dengan Kecamatan Pitumpanua.

Selang 4 tahun setelahnya yakni 2002, areal pelayanan sawah Daerah Irigasi Awo mengalami peningkatan menjadi 2.992 ha yang terdiri 666 ha berada di Kecamatan Keera karena Awo III juga telah berfungsi pada tahun 2000 dan luas lahan di Kecamatan Pitumpanua 2.326 ha.

Selang 4 tahun selanjutnya yakni 2006, areal pelayanan sawah Daerah Irigasi Awo mengalami peningkatan namun yakni 3.010 ha. Luas lahan di Kecamatan Keera tidak meningkat yakni masih 666 ha sedangkan luas lahan di Kecamatan Pitumpanua meningkat menjadi 2.344 ha. Hal ini terjadi karena lahan yang berpotensi menjadi sawah belum juga dikelola menjadi sawah. Hingga tahun 2010 jumlah lahan di Kecamatan Keera hanya bertambah 3 ha sedangkan di Kecamatan Pitumpanua justru mengalami penurunan menjadi 2.325, 50 ha. Terjadi peningkatan pemukiman pendudukan di sekitar jalan poros Makassar-Palopo dimulai dari Desa Kaluku, Desa Alesilurungnge, Kelurahan Tobarakka, dan Kelurahan Bulete, yang menggunakan lahan persawahan di sekitar jalan poros tersebut.

Areal pelayanan Daerah Irigasi Awo mengalami peningkatan hingga tahun 2013 yakni 3.473 ha yang terdiri dari 838 ha lahan di Kecamatan Keera dan 3.473 ha lahan di Kecamatan Pitumpanua. Program percetakan sawah baru dari Dinas Pertanian Kabupaten Wajo dimanfaatkan oleh masyarakat untuk membuka lahan yang berpotensi menjadi sawah irigasi sehingga terjadi penambahan lahan terkhusus di Kecamatan Pitumpanua. Dalam perkembangannya masyarakat yang memiliki lahan potensial kemudian terus dibuka menjadi areal persawahan karena hasil yang lebih menjanjikan. Contoh kasus percetakan sawah baru yakni dari perkebunan kakao milik masyarakat kemudian dijadikan sawah karena bisa dijangkau pengairan.
Hingga tahun 2015 peningkatan areal pelayanan bertambah hingga 4.361 ha, di Kecamatan Keera tetap 838 ha dan Kecamatan Pitumpanua mengalami peningkatan hingga 3.523 ha lahan.

\section{b. Pola Tanam}

Berlangsung pembangunan Awo II pada akhir tahun 1995-1998 serta selesainya Awo III yang dimulai pada tahun 1999-2000 juga mulai menikmati air dari bendung. Hal ini membuat pihak pengelola irigasi Ranting Dinas perlunya melakukan pengaturan air agar tetap berjalan lancar dan merekomendasikan pola tanam ke petani.

Pola tanam yang direkomendasikan pertama kali oleh Ranting Dinas pada awal tahun 2000-an yakni padi, padi, palawija dengan maksud agar pola pertanian berjalan lancar dan tidak merusak unsur hara tanah, karena adanya selang sekali yang dilakukan. Pola pertanian ini juga mengikuti musim tanam secara umum sesuai kondisi berlangsung curah hujan yakni musim rendeng dan musim gadu (Saharuddin, 2018).

Awal mula beralihnya masyarakat dari padi, padi, palawija ke padi, padi, padi bisa dilihat dari pernyataan yang disampaikan oleh Bapak Ambo Asse Petugas Operasi Bendung yang berada di Awo I,

"Awal mula beralih petani di Awo I dari padi, padi, palawija ke padi, padi, padi sekitar tahun 2005/2006, beranggapan bahwa kita dilalui air masa tidak tanam padi yang lebih menjanjikan dibanding palawija. Akhirnya meminta kepada pihak Ranting Dinas Pengairan Awo untuk memberikan air memulai menanam padi. Permintaan petani di Awo I diiyakan dengan catatan Awo II dan III juga harus padi, padi, padi untuk menghindari gesekan antar P3A (Asse, 2018)

Berdasarkan pernyataan di atas sistem tanam padi, padi, padi diawali sekitar tahun 2005/2006 karena dekatnya petani di Awo I 
dengan sumber air sehingga beranggapan bahwa ketika musim gadu Awo I juga masih menanam padi karena dilalui air.

\section{c. Bidang Ekonomi}

Bendung Awo diujicobakan pertama kali pada tahun Desember 1994 dan airnya langsung digunakan oleh petani di Awo I. Hal ini merupakan awal dirasakannya dampak yang telah membawa arah pertanian masyarakat sebelumnya hanya sekali dalam setahun pada musim penghujan kemudian beralih ke pertanian dua kali dalam setahun tanpa bergantung lagi pada musim penghujan untuk sawah irigasi.

Dalam menopang pertanian masyarakat dengan tujuan terjadinya peningkatan produksi hasil pertanian kemudian dirasakan oleh masyarakat. Namun keberadaan Bendung Awo belum mampu menjamin kelancaran pengairan dalam perjalanannya. Untuk memahami hal tersebut dibawa telah disajikan tabel hasil luas panen dan hasil produksi di Kecamatan Keera dan Pitumpanua.

Tabel 4.2 Luas Panen dan Produksi Tanaman Padi di Kecamatan Keera dan Pitumpanua

\begin{tabular}{|c|l|l|l|l|}
\hline \multirow{2}{*}{$\begin{array}{c}\text { Tahu } \\
\mathbf{n}\end{array}$} & \multicolumn{2}{|c|}{ Luas Panen (ha) } & \multicolumn{2}{c|}{ Produksi (ton) } \\
\cline { 2 - 5 } & Keera & $\begin{array}{l}\text { Pitump } \\
\text { anua }\end{array}$ & Keera & $\begin{array}{l}\text { Pitump } \\
\text { anua }\end{array}$ \\
\hline 1996 & - & 14.364 & - & 71.405 \\
\hline 1998 & - & 13.439 & - & 63.500 \\
\hline 2002 & 5.155 & 8.569 & 22.413 & 37.258 \\
\hline 2006 & 3.599 & 6.347 & 17.819 & 33.577 \\
\hline 2010 & 4.022 & 6.855 & 27,050 & 29.751 \\
\hline 2013 & 5.050 & 7.133 & 33.594 & 37.343 \\
\hline 2015 & 6.952 & 10.003 & - & - \\
\hline Sunyyy
\end{tabular}

Sumber: (Badan Pusat Statistik , 1996, 1998, 2002, 2007, 2011, 2014, 2016)

Tabel ini menunjukkan adanya dinamika yang terjadi dalam rentan beberapa tahun setelah berfungsi irigasi. Ternyata hasil produksi sangat dipengaruhi oleh luas panen di setiap kecamatan.
Total produksi di Kecamatan Pitumpanua pada tahun 1996 yakni 71.405 ton dengan luas panen 14.364 ha, Keera masih tergabung di Kecamatan Pitumpanua, artinya belum ada pembagian wilayah sehingga keseluruhan produksi padi berada di Kecamatan Pitumpanua . Berselang dua tahun yakni 1998 luas panen pun menurun dengan angka 13.439 ha mengikut hasil produksi 63.500 ton.

Setelah irigasi difungsikan di Awo III pada tahun 2000 mulai berpengaruh terhadap hasil panen karena irigasi telah dimanfaatkan di beberapa desa di Kecamatan Keera tepatnya di wilayah Awo III. Panen di Kecamatan Keera yakni 5.155 ha sedangkan Pitumpanua 8.569 ha dengan hasil produksi berturut-turut yakni 22.413 ton dan 32.258. Data tentang rata-rata produktivitas antara luas panen dengan hasil produksi belum ada hingga tahun tersebut.

Hal ini terjadi karena areal persawahan yang ada di bagian Keera dan sekitarnya hanya sedikit yang terjangkau irigasi, apalagi irigasi belum selesai di Awo III sehingga sawah tadah hujan tidak dikelola ketika kemarau, berbeda di Pitumpanua areal sawah irigasi sudah terjangkau air. Jadi penurunan hasil produksi itu dipengaruhi di wiliyah Keera dan sekitarnya.

Pada tahun 2006, produksi pertanian mengalami penurunan disebabkan oleh sistem pengaturan air karena adanya animo masyarakat yang ingin menanam padi secara terus-menerus sehingga Awo I dengan Awo II dan III sehingga kekurangan air terjadi karena musim kemarau. Areal persawahan yang berada di sekitar pinggir tambak tidak dijangkau air irigasi.

Hingga tahun 2013 sampai pada tahun 2015 terjadi peningkatan luas panen dan produksi didua kecamatan karena program percetakan sawah baru yang menambah pula areal persawahan irigasi sehingga penanaman padi tetap berlangsung dua kali setahun yang terus menjaga agar produksi setiap tahunnya meningkat atau setidaknya tidak terjadi perbedaan angka yang sangat 
mencolok pada produksi padi yang. Meskipun demikian sawah tadah hujan tetap dikelola ketika musim hujan tiba yang juga berpengaruh pada produksi padi dalam setahunnya di dua kecamatan tersebut.

Sejalan dengan itu dijelaskan oleh salah satu narasumber bahwa sebelum ada irigasi rata-rata produksi petani berkisar diangka 3-5 ton/ha, sangat jarang yang bisa mendapatkan 5 ton dalam satu hektarnya. Setelah berfungsi irigasi kemudian dibarengi dengan teknologi pertanian semacam penggunaan benih dari pemerintah dan berbagai pupuk rata-rata hasil produksi 5-7 ton/ha (Akisman, 2017).

\section{E. Kesimpulan}

Latarbelakang pembangunan Bendung Awo tidak terlepas dari program swasembada pangan pada masa Orde Baru. Dimulai dengan membangun Bendung Awo bersamaan Irigasi Awo I 1992-1995, Awo II 1995-1998 dan 19992000 dibangun Awo III dengan total lahan potensial dan lahan irigasi 2500 ha.

Keberadaan Bendung Awo telah membawa dampak dalam aspek kehidupan masyarakat di Kecamatan Keera dan Pitumpanua yang telah menggunakan manfaatnya. Tentu adanya peningkatan perekonomian setelah berfungsinya irigasi yang menopang pertanian dua kali dalam setahun yakni April-September (musim rendeng) dan Oktober-Maret (musim gadu). Dampak yang telah terjadi yakni diantaranya masyarakat mulai beralih dari tenaga hewan ke tenaga manusia, bertani dua kali dalam setahun, beberapa jalan desa bangun di sekitar saluran irigasi, dan peningkatan hasil produksi padi.

\section{DAFTAR PUSTAKA}

Akisman, 2017. Dampak keberadaan Bendung Awo [Interview] (6 Oktober 2017).

Asse, A., 2018. Latarbelakang terjadi perubahan pola pertanian [Interview] (8 Maret 2018).
Badan Pusat Statistik , 1996, 1998, 2002, 2007, 2011, 2014, 2016. www.bps.wajo.go.id. [Online] Available at: http//www.bps.wajo.go.id [Accessed 73 2018].

Daliman, 2015. Metode Penelitian Sejarah. Yogyakarta: Ombak.

Irwan, A., 2018. Gambaran daerah Irigasi Awo di dua kecamatan [Interview] (8 Maret 2018).

Laodding, 2018. Latar belakang pembangunan Bendung Awo [Interview] (10 Maret 2018).

Loddang, 2018. Reson masyarakat pada saat pembangunan Bendung Awo berlangsung [Interview] (8 April 2018).

Nawas, A., 2018. Wawancara dengan Bapak Abu Nawas di Kantor UPTD Bendung Awo [Interview] (16 Maret 2018).

Pusposutrdjo, S., 2001. Pengembangan Irigasi, Usaha Tani Berkelanjutan dan Gerakan Hemat Air. Jakarta: Direktorat Jenderal Pendidikan Tiinggi Departemen Pendidikan Nasional.

Robert, J. K., 2002. Pengelolaan Sumber Daya Air Dalam Otonomi Daerah. Yogyakarta: Andi Offset.

Saharuddin, 2018. Dampak keberadaan Bendung Awo bagi masyarakat [Interview] (8 Maret 2018).

Sjamsuddin, H., 2007 . Metodologi Sejarah. Yogyakarta: Ombak.

Soetrisno, L., 1998. Pertanian pada Abad ke 21. Jakarta: Direktorat Jenderal Pendidikan Tinggi Departemen Pendidikan dan Kebudayaan.

Supratman, 2018. Wawancara dengan Bapak Supratman via telepon [Interview] (14 April 2018).

UPTD Bendung Awo , 1992. Kontrak Kerjasama PT Waskita Jaya Purnama dengan Dinas PU Provinsi Sulawesi Selatan, Makassar: s.n.

UPTD Bendung Awo, 1993. Tender Evaluation, Kaluku: UPTD Bendung Awo.UPTD Bendung Awo, 1997. Desain Peta Tata Letak Daerah 
Irigasi Awo, Kaluku kabupaten Wajo: s.n.

UPTD Bendung Awo, 2010. Profil

Bendung Awo, Kaluku, Kabupaten Wajo: s.n. 